\title{
Pengawasan Curah Jantung
}

\section{Cardiac output monitoring}

Mochamat Helmi*

*Dokter Spesialis Anestesiologi lulusan FK UGM/ RSUP Dr. Sardjito Yogyakarta, Kandidat PhD pada Department Intensive Care Adults, Erasmus University Medical Center, Rotterdam, The Netherlands

\section{ABSTRACT}

Cardiac ouput has a major role to determine tissue oxygen delivery and blood pressure, therefore its monitoring became fundamental. Uptil now, the thermodilution system remains a gold standard in cardiac output monitoring. However, it is well known that this system has many risks due to its invasive methods. Therefore, the less invasive, safe, accurate and easy to use cardiac output monitorings are under developments. The aim of this review is to describe some cardiac output monitoring methods.

Keywords: cardiac ouput, hemodynamic, hemodynamic monitorings, less invasive.

\begin{abstract}
ABSTRAK
Sebagai faktor penentu dari hantaran oksigen ke jariangan dan juga tekanan darah, curah jantung menjadi komponen penilaian hemodinamik yang penting.Penggunaan teknik thermodilusi yang menjadi standar baku, telah banyak diketahui mempunyai resiko karena teknik invasifnya. Sehingga teknik pengawasan CO yang kurang invasif, aman,akurat dan mudah digunakan, terus mengalami perkembangan. Tinjauan pustaka ini akan mamaparkan mengenai beberapa macam metode pengawasan CO.
\end{abstract}

Kata kunci: cardiac output, hemodinamik, pengawasan hemodinamik, less invasif.

\section{PENDAHULUAN}

Curah jantung / cardiac output (CO) merupakan bagian yang penting diperhatikan dalam tata laksana pasien resiko tinggi pada fase perio-operatif atau di ICU. Pengawasan / monitoring CO pada pasien-pasien sakit kritis sangat dianjurkan untuk dilakukan dengan tujuan untuk membantu mempertahankan oksigenasi jaringan ${ }^{1}$. Karena CO tidak dapat diperkirakan dengan baik dengan menggunakan pemeriksaan fisik atau pemeriksaan rutin lainnya. Nilai $\mathrm{CO}$ sendiri dapat memberikan informasi yang sangat bermanfaat kepada dokter anestesi atau 
intensivist dalam melakukan tata laksana pada pasien dengan masalah yang kompleks ${ }^{2}$.

Pengukuran CO pertama kali dilakukan oleh Adolph Fick pada tahun $1870^{3}$, yang menyebutkan bahwa CO dapat dihitung sebagai rasio antara konsumsi oksigen (VO2) dan beda kadar oksigen pada darah arteri dan vena ${ }^{4}$ :

Penggunaan prinsip Fick membutuhkan kateterisasi arteri pulmoner yang pertama kali dilakukan pada hewan coba (canine) pada tahun 1886 oleh Grehand dan Quinquaud.Tetapi prinsip ini baru dilakukan pada manusia setelah hampir 5 dekade kemudian, pada tahun 1940 di New York ${ }^{3}$. Kemudian ditemukan pengukuran $\mathrm{CO}$ menggunakan teknik dilusi yang dilakukan oleh tim kerja Stewart pada akhir abad ke 19, dan kemudian dimodifikasi oleh Hamilton pada sekitar tahun 1930. Mereka menghitung $\mathrm{CO}$ dengan membagi jumlah indikator yang diinjeksikan, dengan area di bawah kurva dilusi. Teknik dilusi dipandang dapat diaplikasikan pada sebagian besar kondisi klinis, sehingga teknik ini menjadi metode referensi dalam pengukuran CO.Pada pertengahan tahun 1970an, kateter arteri pulmoner / pulmonary artery catheter (PAC) berhasil didesain yang memudahkan didapatkannya kurva thermodilusi dengan menggunakan komputer untuk menganalisa dan menentukan nilai $\mathrm{CO}^{5}$.

Sebagian besar penelitian-penelitian telah menyimpulkan keakuratan teknik
PAC ini. Selain itu dengan pemakaiannya yang relatif mudah, menjadikan PAC sebagai standard baku dalam pengukuran $\mathrm{CO}$. Pemakaian PAC bukan tanpa resiko. Ada banyak penelitian mempertanyakan efektifitas dan keamanan teknik ini ${ }^{6-9}$. Beberapa komplikasi dari penggunaan PAC antara lain adalah kerusakan arteri karotis dan subklavia, pneumothoraks, disritima, perforasi ruang jantung, tamponade, kerusakan katub jantung, serta ruptur arteri pulmoner ${ }^{10,11}$. Hal inilah yang kemudian memotivasi perkembangan teknologi-teknologi terbaru dalam pengukuran $\mathrm{CO}$ yang kurang invasif dan berpotensi untuk lebih aman untuk digunakan $^{2}$. Saat ini telah tersedia beberapa teknik alternatif, seperti oesophageal ultrasonografi Doppler, transoesophageal echokardiografi, bioimpedansi elektris thorakal, dilusi lithium dan analisa gelombang pulsasi (pulse wave analysis), yang kesemuanya relatif tidak invasif apabila dibandingkan dengan PAC ${ }^{12}$.

Beberapa dari teknik ini mampu menilai volume sekuncup / stroke volume (SV) secara berkelanjutan (continuous) dan pula mampu memberikan nilai komponen hemodinamik lain yang dapat memprediksi respon pasien terhadap pemberian cairan, menilai volume preload, dan mengukur saturasi vena sentral secara berkelanjutan. Komponenkomponen tersebut dan nilai CO sangat membantu dalam melakukan penilaian kondisi hemodinamik pasien kritis dengan lebih baik. Hanya saja perlu 


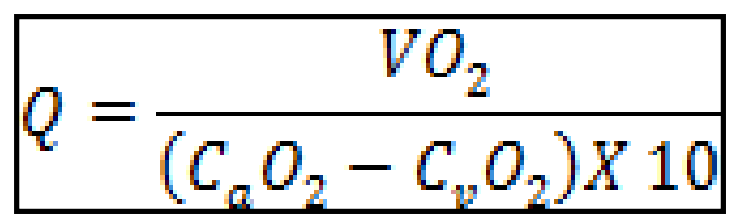

$\mathrm{VO}_{2} \quad$ : konsumsi oksigen ( $\mathrm{ml} \mathrm{O} 2 /$ menit)

$\mathrm{CaO}_{2} \quad$ : kandungan oksigen dalam darah arteri ( $\mathrm{ml} \mathrm{O}_{2} / 100 \mathrm{ml}$ darah)

$\mathrm{CvO}_{2} \quad$ : kandungan oksigen dalam darah vena campuran $\left(\mathrm{ml} \mathrm{O}_{2} / 100 \mathrm{ml}\right.$ darah$)$

Box 1. Rumus Fick.

Tabel 1. Faktor yang mempengaruhi pemilihan alat pengawasan $\mathrm{CO}$

\begin{tabular}{ll}
\hline Institusi & Tipe institusi \\
& Ketersediaan alat \\
& Tingkat standarisasi \\
& Integrasi pada sistem \\
& Jumlah pegawai \\
& Pelatihan dan pengala \\
& \\
Alat & Invasif / non invasif \\
& Kemudahan dalam pe \\
& Keterbatasan teknis \\
& Ketergantungannya pas \\
& Validitas, akurasi dan \\
& Informasi komponen he \\
& Aspek ekonomi \\
& \\
& Keparahan penyakit \\
Pasien & Ritme denyut jantung \\
& Kontraindikasi \\
& Jenis intervensi \\
& Protokol terapi
\end{tabular}

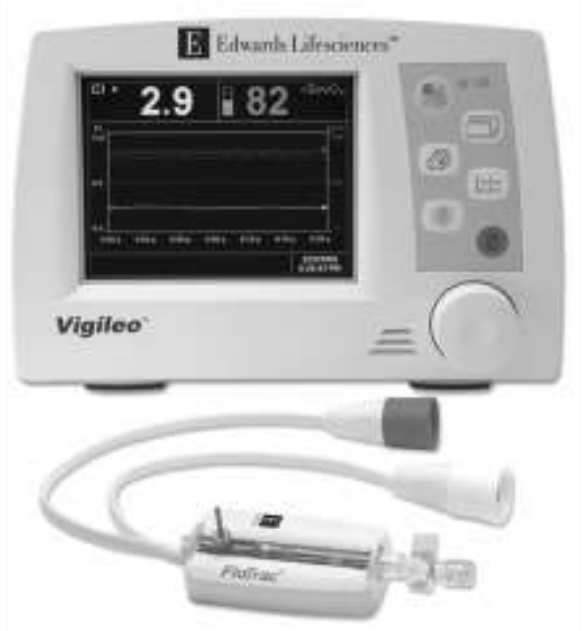

Gambar 1. Sistem FloTrac 
diperhatikan bahwa tidak ada satupun alat pengawan $\mathrm{CO}$ yang tidak mempunyai kelemahan. Oleh karena itu dirasa bijaksana untuk menyesuaikan pula kondisi pasien dalam pemilihan jenis alat pengawasan $\mathrm{CO}^{13}$.

FAKTOR-FAKTOR

YANG MEMPENGARUHI PEMILIHAN ALAT PENGAWASAN CO

Ada baberapa faktor yang dapat mempengaruhi pemilihan alat pengawasan $\mathrm{CO}$, yang dapat diklasifikasikan ke dalam 3 kelompok utama (Tabel 1). Faktor institusi dianggap sebagai faktor yang paling penting. Selain itu faktor alat (invasif/ non invasif) dapat pula berperan. Lebih jauh lagi, kondisi pasien dapat menentukan apakah pasien memerlukan alat invasif atau yang non invasif ${ }^{2}$.

\section{ANALISA PULSASI KONTUR}

Saat ini telah tersedia beberapa alat yang menggunakan teknik analisa pulsasi kontur (pulse countour analysis) untuk menentukan nilai $\mathrm{CO}$, seperti FloTrac, PiCCO, dan LiDCO, yang masing-masing berbeda dalam kebutuhannya terhadap pengawasan invasif dan kalibrasi eksternal. Metode analisa pulsasi kontur dalam menilai CO menggunakan variasi gelombang tekanan pulsasi / pulse pressure (PP).

Secara umum, semakin besar SV, semakin banyak darah dipompa ke sistem arterial pada setiap denyut jantung. Sehingga semakin besar peningkatan dan penunurunan tekanan saat sistolik dan diastolik akan menyebabkan semakin bertambahnya $\mathrm{PP}^{2}$. Nilai PP proporsional terhadap nilai SV dan berbanding terbalik dengan compliance vaskuler. Perubahan gelombang PP dapat diprediksi dari compliance dinding arterial dan SV. Karena compliance vaskuler tidak mudah untuk dinilai, maka nilai tersebut dapat dihitung berdasarkan umur, jenis kelamin, etnis, dan body mass index $(\mathrm{BMI})^{14}$.Menggunakan rumus yang kompleks, metode-motode non-invasif tersebutdapat menilai CO dari analisa pulsasi kontur ${ }^{15}$. Idealnya, analisa pulsasi kontur dikalibrasi dengan menggunakan metode dilusi. Dimana SV dihitung dan dibandingkan dengan SV yang didapatkan dari metode thermodilusi, untuk dapat menghitung CO. Dengan analisa gelombang berkelanjutan tiap denyut / beat-to-beat, CO dapat dinilai secara berkelanjutan $^{16}$.Kalibrasi eksternal disarankan untuk dilakukan tiap 6 sampai dengan 12 jam untuk menjaga keakuratan nilai yang didapatkan ${ }^{15,17}$.

Meskipun nilai CO dari analisa pulsasikontur menunjukkan nilai kesepahaman yang baik dengan analisa $\mathrm{CO}$ dengan teknik lain, tetapi pengunaan obat-obatan vasoaktif (vasodilator/ vasokonstriktor) dapat menyebabkan kesalahan dalam perhitungan $\mathrm{CO}{ }^{16,18}$. Lebih penting lagi, teknik ini dapat juga menghitung variasi tekanan pulsasi / pulse pressure variation (PPV) dan variasi SV (SVV) pada pasien dengan ventilasi tekanan positif. Lebarnya PPV/ 


\section{CO = Dosis LiCl x 60 area $\times(1-$ hematokrit $)$ l/menit}

$\mathrm{CO}=$ cardiac output

$\mathrm{LiCl}=$ dosis lithium $(\mathrm{mmol})$

Area $=$ integral dari kurva primer (mmol/liter), yang merupakan kurva yang dihasilkan pada 1 kali sirkulasi lithium,

Box 2. Penghitungan CO pada system LiDCO

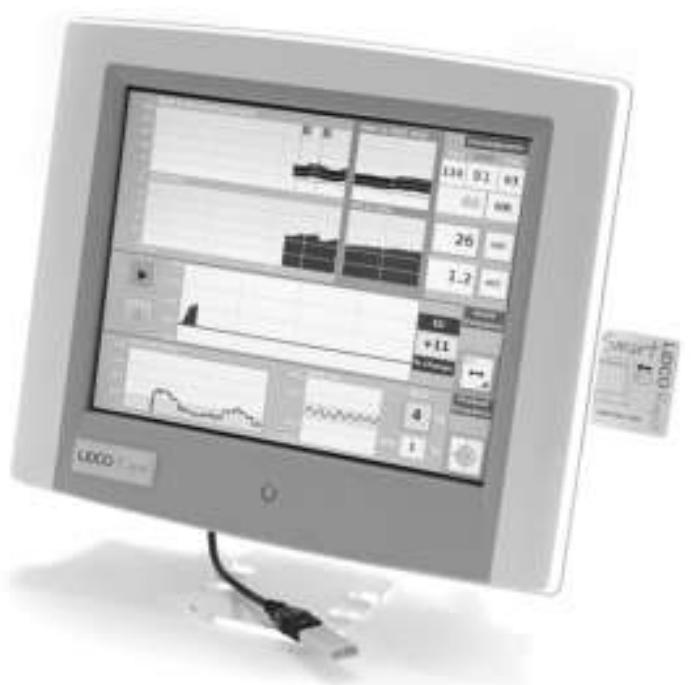

Gambar 2. Sistem LIDCO

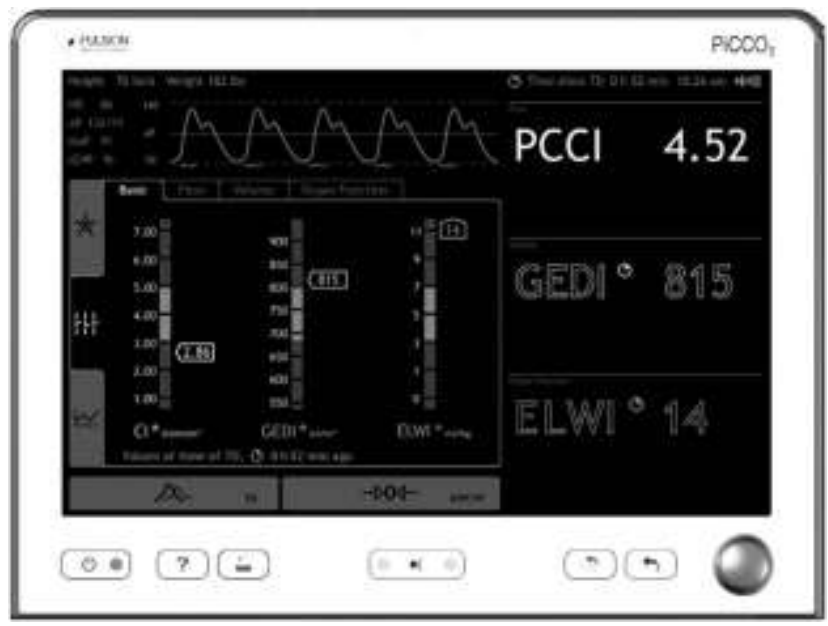

Gambar 3. Sistem PiCCO 
SVV (10\% sampai dengan 15\%) menandakan adanya hipovolemia yang prediktif terhadap respon cairan ${ }^{2}$.

\section{FloTrac}

Sistem FloTrac (Gambar 1) diperkenalkan di Amerika Serikat oleh Edwards Lifesciences, Irvine, CA, pada bulan April 2005. Sistem ini diperkenalkan sebagai alat yang dapat melakukan penilaian $\mathrm{CO}$, resistensi vaskuler sistemik, dan parameter dinamis (SVV) secara berkelanjutan dengan cepat dan akurat ${ }^{2}$.

Sistem ini sangat bergantung pada algoritma perangkat lunak yang melakukan analisa terhadap karakteristik gelombang tekanan arterial dan menggunakan informasi demografi spesifik untuk menilai aliran darah. FloTrac mempunyai beberapa fungsi yang bermanfaat secara klinis. Pertama, sistem ini secara teoritis dapat digunakan pada tiap jalur kateter arterial; tidak diperlukan adanya kateter tambahan. Selain itu, tidak ada batasan dalam lokasi kanulasi arterial ${ }^{2}$.

Sistem ini telah digunakan pada beberapa penelitian dimana disimpulkan bahwa sistem ini dapat menyediakan nilai yang akurat baik dari kateter femoral ataupun radial ${ }^{19,20}$.Beberapa penelitian menemukan adanya perbedaan dalam penilaian $\mathrm{CO}$ dari beberapa lokasi kateterisasi yang berbeda, terutama pada pasien dengan hemodinamik tidak stabil dan/atau dengan pennggunaan vasopresor.
Kesalahan yang bermakna ditemui pada pangukuran $\mathrm{CO}$ oleh FloTrac apabila terdapat perbedaan mean arterial pressure (MAP) antar 2 lokasi kateterisasi bernilai lebih dari $5 \mathrm{~mm}$ $\mathrm{Hg}^{2}$. Keunggulan lain dari sistem FloTrac ini adalah bahwa sistem ini tidak membutuhkan kalibrasi eksternal. Analisa algoritma kontur yang dilakukan oleh sistem FloTrac melakukan kalibrasi secara otomatis yang bedasarkan data demografis pasien dan analisa gelombang.Kalibrasi ini dapat disesuaikan dengan data individu pasien, termasuk tonus vaskuler ${ }^{2}$.

\section{LiDCO}

Sistem LiDCO (Gambar 2) dikembangkan oleh kelompok LiDCO dan diperkenalkan pada praktik klinis pada awal dekade ini. Seperti halnya sistem FloTrac, sistem in imenggunakan analisa pulsasi kontur dari jalur arterial untuk menentukan $\mathrm{SV}$ dan $\mathrm{CO}^{2}$. Perbedaan yang paling bermakna dari kedua teknologi ini terdapat pada metode kalibrasi analisa kontur. Beda halnya dengan sistem FloTrac yang tidak menggunakan kalibrasi eksternal, sistem LiDCO menggunakan dilusi lithium untuk kalibrasi analisa algoritma pulsasi kontur. Kalibrasi ini dapat dilakukan dengan melakukan injeksi lithium klorida dalam jumlah kecil ke dalam vena sentral (disarankan) atau perifer. Elektroda yang sensitif terhadap lithium ditempatkan pada kateter arterial yang digunakan untuk menentukan kurva konsentrasi berdasarkan waktu untuk menghitung nilai $\mathrm{CO}^{21}$. 
Setelah dilakukan kalibrasi, sistem LiDCO dapat melakukan pengukuran $\mathrm{CO}$ dengan menggunakan analisa pulsasi kontur. Kalibrasi eksternal dengan lithium ini tidak perlu diulang. Pada umumnya, disarankan kalibrasi dilakukan paling tidak setiap 8 jam. Tetapi, beberapa penelitian menyebutkan bahwa apabila dilakukan perubahan terapi yang bermakna, termasuk dilakukan bolus cairan, maka disarankan untuk dilakukan kalibrasi lebih sering. ${ }^{14,22}$.

Hanya saja, akurasi pengukuran CO dari analisa dengan sistem ini belum diteliti dengan mendalam. Populasi pasien yang kecil, perbedaan setting penelitian, dan perbedaan standard baku menjadikan membuat penyamaan hasil (generalisasi) hampir tidak mungkin untuk dilakukan. Beberapa peneliti menyebutkan bahwa sistem ini akurat ${ }^{23}$ dan ada yang menyebutkan sebaliknya ${ }^{24,25}$. Sehingga lebih pastinya, penelitian lebih lanjut masih diperlukan untuk dapat menunjukkan kemampuan sistem LiDCO untuk menyediakan pengkuran $\mathrm{CO}$ di setting perioperatif ${ }^{2}$.

LiDCO dapat menunjukkan hemodinamik $^{2}$ : 1. Tekanan (sistolik, diastolic, dan rerata); 2. Laju denyut jantung; 3. SV dan CO; dan 4. Parameter preload dinamis (PPV dan SVV).

\section{PiCCO}

Sistem PiCCO (Gambar 3) dikembangkan oleh Pulsion Medical yang disetujui untuk digunakan pada praktek klinis pada tahun 2000. Seperti halnya sistem LiDCO dan FloTrac, sistem ini memberikan penilaiaan $\mathrm{CO}$ melalui analisa pulsasi kontur dari gelombang arterial. Seperti halnya sistem LiDCO, sistem ini membutuhkan kalibrasi eksternal untuk memulai analisa $^{2}$. Dengan teknik ini, ujung kateter biasanya berada di aorta desenden melalui jalur femoral. Saline dingin $(15 \mathrm{~mL})$ diinjeksikan melalui vena sentralis. Penilaian $\mathrm{CO}$ dan kalibrasi sistem pulsasi kontur didapatkan setelah terjadi perubahan temperatur di aorta akibat injeksi saline dingin tersebut [26-28]. Selain analisa $\mathrm{CO}$, PiCCO juga dapat memberikan beberapa pengukuran lain yang bermanfaat di kamar operasi dan ICU. Penilaian volume akhir diastolik global (global end-diastolic volume) dari empat ruang jantung memberikan penilaian terhadap preload jantung. Volume darah intra-thoraks juga dapat digunakan untuk menilai preload. Komponen ini termasuk volume pada sistem pulmoner selain volume darah di dalam jantung. Sedangkan indeks fungsi jantung mencerminkan kontraktilitas global dan rasio aliran dan preload. Cairan ekstra vaskular paru (extravascular lung water) menunjukkan cairan pada ruang intraseluler, intersitisial, dan intraalveoler yang merupakan metode untuk menilai edema pulmoner ${ }^{2}$.

PiCCO dapat menunjukkan parameterparameter dinamis untuk menunjukkan responsivitas terhadap cairan. Selain itu, 
teknik ini juga dapatmenunjukkan data hemodinamik yang sangat bermanfaat untuk memahami kondisi fisiologis pasien ${ }^{2}$ yaitu 1. Responsivitas terhadap cairan: PPV dan SVV; 2. CO Thermodilusi transpulmoner dan Analisa pulse contour; 3. Extravascular lung water index (EVLWI): membantu penilaian edema pulmoner; 4. Global end-diastolic volume index (GEDI): membantu menilai volumetric preload; 5. Cardiac function index yaitu kalkulasi indeks dari fungsi jantung

Salah satu kekurangan dari teknik ini adalah perlunya kateterisasi arteri proksimalis dengan kateter khusus (thermistorstipped).

Produsen menyarankan pengunaan kateterisasi arteri femoral, aksiler atau brakhial.Penggunaan arteri radialis mempunyai 2 kekurangan apabila dibandingan dengan arteri pada lokasi yang lebih proksimal. Pertama, penyimpangan gelombang akibat area kateterisasi menjadi diminimalisir, sehingga analisa pulsasi kontur menjadi kurang rentan terhadap kesalahan sebagai akibat dari vasokonstriktor thermoregulasi atau akibat penggunaan vasopressor $^{26}$. Kedua, apabila dibandingkan dengan arteri radialis, area arteri lainnya yang disebutkan sebelumnya memberikan hasil yang dapat diprediksi, dengan kondisi suhu yang homogennya untuk mendapatkan pengukuran thermodilusi transpulmoner. Selain variabilitas ekstremitas, jarak yang lebih jauh untuk transit intravaskuler menyebabkan terjadinya proses penghangatan indikator thermal oleh massa tubuh ekstravaskuler ${ }^{27,28}$, yang mengakibatkan perubahan temperatur terukur menjadi kurang reflektif dibandingkan dengan dilusi sesungguhnya ${ }^{2}$.

Ada beberapa situasi klinis dimana tidak semua parameter-parameter PiCCO bernilai valid. Thermodilusi transpulmoner mempunyai beberapa keterbatasan seperti perhitungan thermodilusi menggunakan PAC. Seperti selama periode resusitasi atau penggunaan katekolamin, dimana diperlukan adanya rekalibrasi. Beberapa penulis melaporkan bahwa CO pulsasi kontur yang didapatkan dari PiCCO senilai dengan $\mathrm{CO}$ yang didapatkan dengan menggunakan thermodilusi CO berkelanjutan atau intermiten ${ }^{29,30}$.

\section{ULTRASONOGRAFI OESOPHAGEAL DOPPLER}

Pengawasan CO dengan menggunakan oesophageal Doppler dapat mengukur velositas aliran darah di dalam aorta desenden $^{30}$. Dengan menggunakan perubahan frekuensi gelombang ultrasound yang dapat mencerminkan obyek yang bergerak (akibat perpindahan Doppler), maka velositas aliran darah dapat dinilai. Apabila pengukuran ini dikombinasi dengan estimasi area potong lintang dari aorta yang didapatkan dari umur, tinggi dan berat badan pasien, maka akan didapatkan komponen hemodinamik seperti SV, CO dan cardiac index. Metode ini mempunyai keunggulan 
karena dapat menunjukkan pengukuran yang berkelanjutan, dengan syarat keakuratan komponen berikut dapat diperoleh: 1. area potong lintang aorta harus akurat; 2. gelombang ultrasound harus paralel terhadap aliran darah; 3.arah gelombang tidak berubah ke derajad manapun antar pengukuran / penilaian.

Variasi dari kondisi-kondisi tersebut menyebabkan ketidak akuratan pengukuran.

Curah jantung dan SV yang didapatkan dari oesophageal Doppler telah dibandingkan dengan thermodilusi pada beberapa penelitian, dan dari penelitianpenelitian tersebut, rentang didapatkan dari korelasi buruk ke baik ${ }^{31-33}$. Sebuah meta analisis yangdilakukan oleh Dark dan Singer $^{34}$ menunjukkan adanya korelasi sebesar $86 \%$ antara CO yang didapatkan dari Doppler esophageal deangan PAC. Meskipun korelasi antara dua teknik tersebut bernilai moderat, ada korelasi yang sangat baik antara perubahan $\mathrm{CO}$ dengan intervensi terapetik. Sehingga perubahan $\mathrm{CO}$ akibat respon terapi tersebut dapat menjadi lebih bermanfaat apabila dibandingkan dengan nilai absolut itu sendiri ${ }^{22}$.

Esophageal Doppler merupakan teknik non invasif yang telah dengan baik dapat digunakan untuk membantu secara langsung dalam pemberican cairan intra operatif 35 . Kelemahan utama dari penggunaan teknik ini sebagai pengawasan $\mathrm{CO}$ berkelanjutan adalah hubungannya dengan ketepatan yang menunjukkan responsibilitas dari sebuah penilaian. Teknik ini sangat bergantung pada kepiawaian operator dan posisi probe yang sangat mudah berubah pada saat dilakukan penilaian,sehingga dapat mengurangi preisis penilaian yang dilakukan $^{36}$. Hal ini kemudian dapat mengurangi korelasi antara esophageal Doppler dengan teknik monitoring CO lainnya ${ }^{37,38}$. Selain itu, teknik ini dapat mengukur aliran darah pada aorta desenden dan membuat asumsi dari partisi tetap antara aliran ke pembuluh darah cefalika dan ke aorta desenden. Meskipun teknik ini dinilai valid pada kondisi sehat, korelasi tersebut dapat berubah pada pasien dengan penyakit tertentu, dan pada beberapa kondisis seperti pada kondisi ketidakstabilan hemodinamik. Dan juga, area potong lintang aorta tidak bernilai konstan, tetapi dinamis untuk tiap individu. Sehingga penggunaan normogram dapat mengakibatkan kekurangakuratan penilaian $\mathrm{CO}^{24}$.

Pasien biasanya dalam kondisi tersedasi, dengan ventilator. Probe kemudian melalui esophagus kemudian diputar sedemikian rupa sehingga transduser menghadap aorta desenden, sehingga didapatkan signal velositas aorta ${ }^{30}$. Penggunaan probe pada teknik ini dapat diterima dengan baik pada pasien yang dalam kondisi sadar (tidak ideal), tetapi memerlukan penempatan posisi pasien yang baik, dan membutuhkan perubahan posisi yang berulang kali ${ }^{12}$. 
TRANSESOPHAGEAL ECHOCARDIOGRAPHY (TEE)

Curah jantung dapat dinilai dengan menggunakan TEE menggunakan metode Dopper atau non-Doppler. Teknik Non-Doppler dilakukan berdasarkan rekonstruksi volumetrik dari rekonstruksi ruang ventrikel kiri. Metode yang paling sering dilakukan adalah menggunakan hukum Simpson, dimana ventrikel kiri dibagi menjadi beberapa seri dari basal ke apeks jantung. Dua plana orthogonal digunkaan untuk rekonstruksi. Volume ventrikel kiri kemudian dihitung dengan menjumlahkan perkiraan volume pada diskus individual $^{2}$.Teknik ini dapat digunakan untuk menghitung SV yang kemudian apabila dikalikan dengan denyut jentung akan memberikan nilai $\mathrm{CO}^{12}$.

Prinsipnya, echokardiografi merupakan metode yang mudah untuk menilai fungsi jantung karena menggunakan gelombang ultrasound untuk mendapatkan pencitraan jantung secara langsung. Metode ini dapat menilai ukuran ruangan jantung, kontraktilitas ventrikel, fungsi ventrikel, dan dengan bantuan Doppler dapat pula menilai aliran ${ }^{23,24}$. Hanya saja, metode ini membutuhkan kepiawaian yang baik untuk dapat melakukan interpretasi hasil pencitraan, dan dapat terjadi banyak sekali perbedaan variasi interpretasi hasil pencitraan. Pertimbangan lain dari penggunaan teknik ini adalah harga dari alat tersebut ${ }^{30}$.
Penilaian CO dapat dilakukan pada level arteri pulmoner, katub mitralis atau katub aorta, meskipun beberapa penelitian menunjukkan bahwa sangat sukar untuk mengukur diameter dari arteri pulmoner yang dapat menjelaskan rendahnya korelasi penilaian $\mathrm{CO}$ antara Doppler dan thermodilusi. Penilaian pada katub mitralis dapat lebih sukar karena bentuk dan ukuran katub yang berubah tiap siklus jantung, sehinggakatub aorta bukan menjadi pilihan utama untuk penilian CO dengan Doppler. Ketidakberadaannya stenosis aorta pada metode ini merupakan kondisi penilaian yang paling $\mathrm{CO}$ akurat ${ }^{39}$. Beberapa penelitian telah menunjukkan korelasi yang baik antar penilaian $\mathrm{CO}$ dengan menggunakan teknik thermodilusi pada kondisi katub mitral yang kompeten ${ }^{40}$.

Alat ultrasound portable yang lebih terkini dapat melakukan pemeriksaan jantung dan evaluasi fungsi dinamik jantung. Penilaian fungsi ventrikuler secara umum bermanfaat untuk tata laksana pasien kritis ${ }^{19}$. Pasien dengan disoksia jaringan dan hiperkontraktilitas ventrikel kiri dapat mendapatkan manfaat dari penggunaan vasopressor dan/atau pemberian cairan, sedangkan pasien dengan fungsi ventrikel yang buruk dapat mendapatkan manfaat dari penggunaan inotropik. Dilatasi ventrikel dapat memberikan peringatan kepada intensivist untuk melihat adanya disfungsi ventrikel kanan. Dengan pelatihan dasar, penilaian ini dapat 


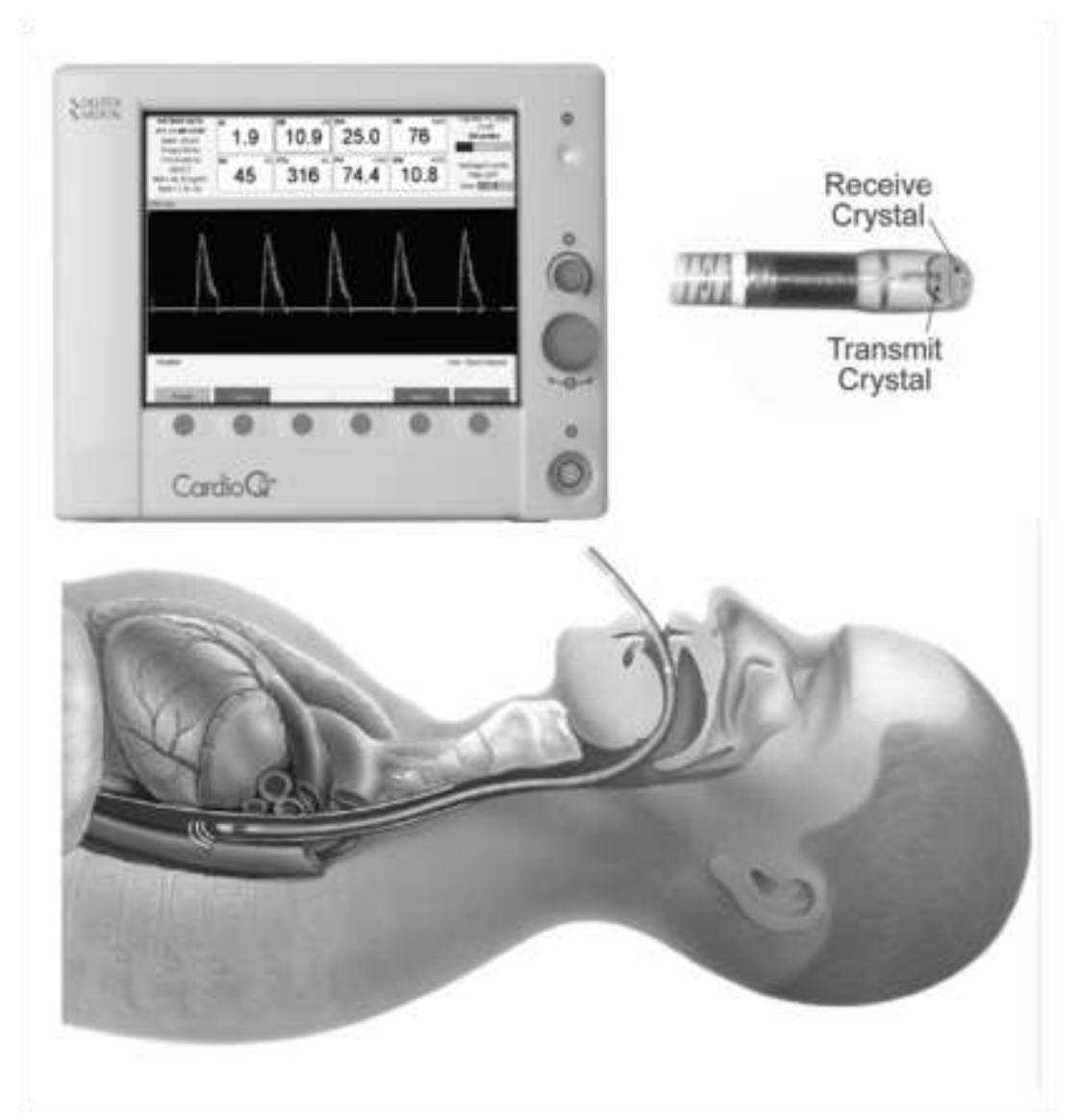

Gambar 4. Sistem Ultrasonografi Oesophageal Doppler

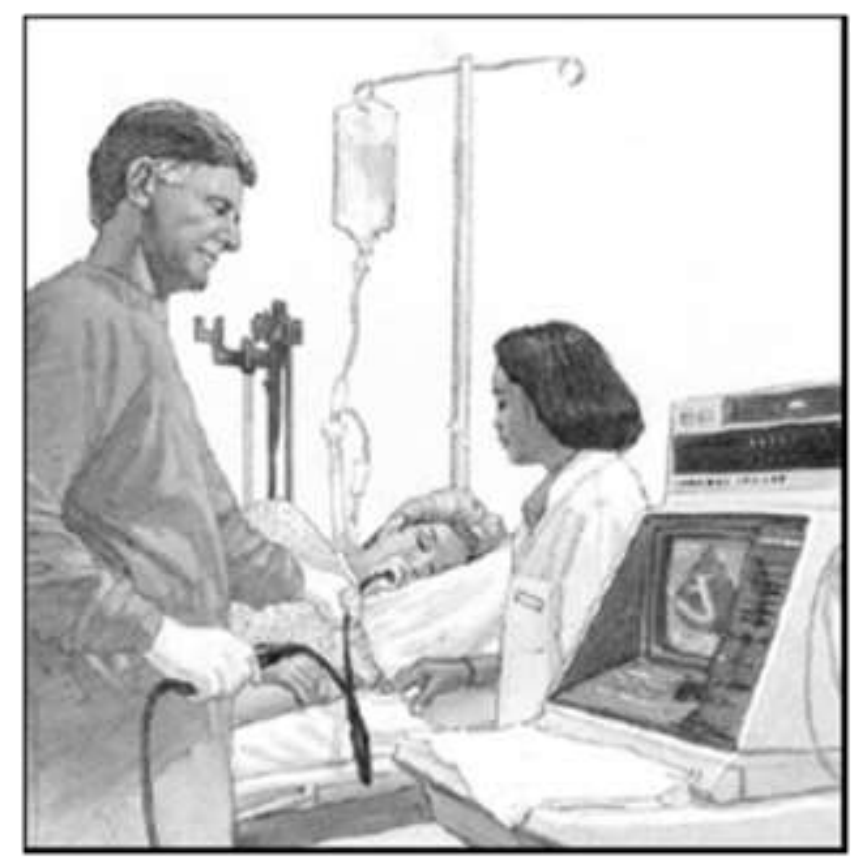

Gambar 5. Sistem Transesophageal Echocardiography (TEE) 
dipelajari oleh selain ahli jantung, tetapi menentukan abnormalitas gerakan dinding jantung dan fungsi katub masih membutuhkan ketrampilan seorang ahli jantung.

Ukuran ruang jantung dapat dinilai secara langsung dengan menghitung fraksi ejeksi jantung. Aliran darah melalu katub-katub jantung dapat diukur dengan pencitraan Doppler ini.Hanya saja, kesukaran teknik ini adalah untuk mendapatkan pencitraan yang adekuat pada plana yang tepat, yang membutuhkan keahlian khusus. Transoesophageal echokardiografi tidak dapat ditoleransi pada pasien sadar penuh $^{12}$.

\section{NICO: FICK'S PRINCIPLE}

Sistem NICO diperkenalkan pertama kali oleh Novametrix pada tahun 1999. Sistem ini menilai CO melalui beberapa teknik re-breathing parsial yang diperkenalkan oleh Fick ${ }^{2}$. Teknik ini menggunakan re-breathing parsial $\mathrm{CO} 2$ yang membandingkan tekanan parsial end-tidal carbon dioxide (etCO2) yang didapatkan saat periode non re-breathing dengan yang didapatkan saat periode rebreathing selanjutnya. Perubahan rasio pada eliminasi etCO2 dan eliminasinya setelah periode singkat re-breathing parsial (biasanya 50 detik) memberikan perkiraan $\mathrm{CO}$ non invasif. Teknik ini menggunakan sensor $\mathrm{CO} 2$ infra merah, dengan ujungnya yang dapat menilai perbedaan tekanan, dan katub rebreathing yang menilai eliminasi $\mathrm{CO} 2$ melalui integrasi dari konsentrasi antara aliran darah dan $\mathrm{CO} 2$ tiap 3 menit setelah periode singkat dari re-breathing parsial untuk menghitung aliran darah pulmoner ${ }^{41}$. Nilai aliran darah pulmoner kemudian dikoreksi untuk shunt menggunakan kurva pada sistem tersebut, yang kemudian membutuhkan informasi $\mathrm{SpO} 2$ atau analisa gas darah dan FiO2 untuk menentkan $\mathrm{CO}^{2}$. Selain $\mathrm{CO}$, teknik ini juga menunjukkan ventilasi semenit dari alveoli dan beberapa parameter respirasi lainnya ${ }^{2}$.

Teknik pengawasan NICO membutuhkan intubasi endotracheal. Alat ini dikontraindikasikan pada pasein yang tidak dapat mentoleransi periode re -breathing dengan sedikit peningkatan $\mathrm{PaCO} 2$. Selain katub rebreathing yang meningkatkan ruang mati jalan nafas (sampai minimal $35 \mathrm{~mL}$ ) dan membutuhkan perubahan pada setting ventilator, terutama pada pasien yang diventilasi dengan volume tidal rendah ${ }^{2}$. Pada pasien yang bernafas spontan, periode re-breathing berhubungan dengan peningkatan ventilasi semenit.

Batasan dari metode penilaian $\mathrm{CO}$ dengan mengggunakan CO2re-breathing adalah karena metode ini hanya menilai aliran darah pulmoner kapiler.Dengan memperhatikan keterbatasan data pada pasien di ICU dan potensi ketidakakuratan pada populasi pasien ini, penggunaan teknik $\mathrm{CO} 2$ re-breathing untuk memperkirakan $\mathrm{CO}$ secara rutin tidak direkomendasikan untuk saat ini. 


\section{BIOIMPEDANSI}

\section{THORAKAL}

Konsep analisa panjang gelombang impedansi thorakal pertama kali diperkenalkan padatahun 1966 oleh Kubicek $^{42}$. Impedansi plethysmografi berdasarkan pada perubahan pulsatil pada resistensi yang tejadi pada siklus ventrikel sistole dan diastole. Bioimpedansi elektrik menggunakan stimulasi elektrik untuk identifikasi variasi impedansi thoraks atau tubuh yang mengasilkan perubahan siklik pada aliran darah yang disebabkan oleh denyut jantung. CO dapat diperkirakan secara berkelanjutan dengan elektroda yang ditempatkan pada leher dan thoraks ${ }^{12}$.

Peubahan pada impedansi berkorelasi dengan SVdan menyebabkan SVdapat dihitung dengan mengggunakan rumus Kubicek's atau rumus ${ }^{12}$. COdapat dihitung dengan menggunakan SV dan waktu ejeksi ventrikuler. Penempatan elektroda dapat menjadi sumber utama kesalahan dalam perhitungan. Faktor lain yang mempengaruhi penilaian bioimpedansi termasuk perubahan cairan intrathorakal dan perubahan nilai hematokrit. Selan itu, siste mini dapat memberikan manfaat pada klinisi untuk dapat dengan cepat dan mudah menentukan $\mathrm{CO}$ dengan resiko minimal 43. Baru-baru ini telah diperkenalkan Bioreactance ${ }^{\circledR} \quad(\mathrm{NICOM} \AA$, Cheetah Medical Ltd, Maidenhead, Berkshire, UK) yang suatu modifikasi dari bioimpedansi thoraks ${ }^{32}$. Kebalikan dari bioimpedansi, yang berdasarkan analisa perubahan voltase amplitudo

\section{SIMPULAN}

Ringkasnya, tiap teknik pengukuran CO mempunyai kelebihan dan kekurangannya masing-masing. Sampai saat ini masih terus dikembangkan metode pengawasan $\mathrm{CO}$ yang kurang invasif, aman, mudah digunakan, dan akurat. Sangat tidak mungkin untuk menyebutkan secara pasti teknologi mana yang paling akurat dalam pengukuran $\mathrm{CO}$ untuk tiap kondisi pasien.

\section{DAFTAR PUSTAKA}

1. Connors AF, Jr., Speroff T, Dawson NV, Thomas C, Harrell FE, Jr., Wagner D, Desbiens N, Goldman L, Wu AW, Califf RM et al: The effectiveness of right heart catheterization in the initial care of critically ill patients. SUPPORT Investigators. Jama 1996, 276(11):889-897.

2. Pugsley J, Lerner AB: Cardiac output monitoring: is there a gold standard and how do the newer technologies compare? Semin Cardiothorac Vasc Anesth 2010, 14 (4):274-282.

3. Laszlo G: Respiratory measurements of cardiac output: from elegant idea to useful test. J Appl Physiol 2004, 96(2):428-437.

4. Young BP, Low LL: Noninvasive monitoring cardiac output using partial $\mathrm{CO}$ (2) rebreathing. Crit Care Clin 2010, 26 (2):383-392, table of contents.

5. Harvey S, Harrison DA, Singer M, Ashcroft J, Jones CM, Elbourne D, Brampton W, Williams D, Young D, Rowan K et al: Assessment of the clinical effectiveness of pulmonary artery catheters in management of patients in intensive care (PAC-Man): a randomised controlled trial. Lancet 2005, 366(9484):472-477.

6. Sakr Y, Dubois MJ, De Backer D, Creteur J, Vincent JL: Persistent microcirculatory alterations are associated with organ failure 
and death in patients with septic shock. Crit Care Med 2004, 32(9):1825-1831.

7. Lam C, Tyml K, Martin C, Sibbald W: Microvascular perfusion is impaired in a rat model of normotensive sepsis. J Clin Invest 1994, 94(5):2077-2083.

8. De Backer D, Creteur J, Preiser JC, Dubois MJ, Vincent JL: Microvascular blood flow is altered in patients with sepsis. Am J Respir Crit Care Med 2002, 166(1):98-104.

9. Lindert J, Werner J, Redlin M, Kuppe H, Habazettl H, Pries AR: OPS imaging of human microcirculation: a short technical report. J Vasc Res 2002, 39(4):368-372.

10. Boyd KD, Thomas SJ, Gold J, Boyd AD: A prospective study of complications of pulmonary artery catheterizations in 500 consecutive patients. Chest 1983, 84(3):245 -249 .

11. Horst HM, Obeid FN, Vij D, Bivins BA: The risks of pulmonary arterial catheterization. Surg Gynecol Obstet 1984, 159(3):229-232.

12. Hett DA, Jonas MM: Non-invasive cardiac output monitoring. Intensive Crit Care Nurs 2004, 20(2):103-108

13. Alhashemi JA, Cecconi M, Hofer CK: Cardiac output monitoring: an integrative perspective. Crit Care 2011, 15(2):214.

14. Brumfield AM, Andrew ME: Digital pulse contour analysis: investigating agedependent indices of arterial compliance. Physiol Meas 2005, 26(5):599-608.

15. Pittman J, Bar-Yosef S, SumPing J, Sherwood M, Mark J: Continuous cardiac output monitoring with pulse contour analysis: a comparison with lithium indicator dilution cardiac output measurement. Crit Care Med 2005, 33 (9):2015-2021.

16. Bein B, Worthmann F, Tonner PH, Paris A, Steinfath M, Hedderich J, Scholz J: Comparison of esophageal Doppler, pulse contour analysis, and real-time pulmonary artery thermodilution for the continuous measurement of cardiac output. J Cardiothorac Vasc Anesth 2004, 18(2):185189.
17. Schuerholz T, Meyer MC, Friedrich L, Przemeck M, Sumpelmann R, Marx G: Reliability of continuous cardiac output determination by pulse-contour analysis in porcine septic shock. Acta Anaesthesiol Scand 2006, 50(4):407-413.

18. Berberian G, Quinn TA, Vigilance DW, Park DY, Cabreriza SE, Curtis LJ, Spotnitz HM: Validation study of PulseCO system for continuous cardiac output measurement. ASAIO J 2005, 51(1):37-40.

19. Beaulieu Y, Marik PE: Bedside ultrasonography in the ICU: part 1. Chest 2005, 128(2):881-895.

20. Beaulieu Y, Marik PE: Bedside ultrasonography in the ICU: part 2. Chest 2005, 128(3):1766-1781.

21. Tachibana $\mathrm{K}$, Imanaka $\mathrm{H}$, Takeuchi $\mathbf{M}$, Takauchi Y, Miyano H, Nishimura M: Noninvasive cardiac output measurement using partial carbon dioxide rebreathing is less accurate at settings of reduced minute ventilation and when spontaneous breathing is present. Anesthesiology 2003, 98(4):830837.

22. Roeck M, Jakob SM, Boehlen T, Brander L, Knuesel R, Takala J: Change in stroke volume in response to fluid challenge: assessment using esophageal Doppler. Intensive Care Med 2003, 29(10):17291735 .

23. Garcia-Rodriguez C, Pittman J, Cassell CH, Sum-Ping J, El-Moalem H, Young C, Mark JB: Lithium dilution cardiac output measurement: a clinical assessment of central venous and peripheral venous indicator injection. Crit Care Med 2002, 30 (10):2199-2204.

24. Jonas MM, Tanser SJ: Lithium dilution measurement of cardiac output and arterial pulse waveform analysis: an indicator dilution calibrated beat-by-beat system for continuous estimation of cardiac output. Curr Opin Crit Care 2002, 8(3):257-261.

25. Linton NW, Linton RA: Estimation of changes in cardiac output from the arterial blood pressure waveform in the upper limb. Br J Anaesth 2001, 86(4):486-496.

26. Ostergaard M, Nielsen J, Rasmussen JP, Berthelsen PG: Cardiac output--pulse 
contour analysis vs. pulmonary artery thermodilution. Acta Anaesthesiol Scand 2006, 50(9):1044-1049.

27. Halvorsen PS, Espinoza A, Lundblad R, Cvancarova M, Hol PK, Fosse E, Tonnessen TI: Agreement between PiCCO pulse-contour analysis, pulmonal artery thermodilution and transthoracic thermodilution during off-pump coronary artery by-pass surgery. Acta Anaesthesiol Scand 2006, 50(9):1050-1057.

28. Sakka SG, Reinhart K, Meier-Hellmann A: Comparison of pulmonary artery and arterial thermodilution cardiac output in critically ill patients. Intensive Care Med 1999, 25(8):843-846.

29. Shoemaker WC, Belzberg $\mathrm{H}$, Wo CC, Milzman DP, Pasquale MD, Baga L, Fuss MA, Fulda GJ, Yarbrough K, Van DeWater JP et al: Multicenter study of noninvasive monitoring systems as alternatives to invasive monitoring of acutely ill emergency patients. Chest 1998, 114 (6):1643-1652.

30. Marik PE, Baram M: Noninvasive hemodynamic monitoring in the intensive care unit. Crit Care Clin 2007, 23(3):383400.

31. Donovan KD, Dobb GJ, Newman MA, Hockings BE, Ireland M: Comparison of pulsed Doppler and thermodilution methods for measuring cardiac output in critically ill patients. Crit Care Med 1987, 15(9):853857.

32. Siegel LC, Fitzgerald DC, Engstrom RH: Simultaneous intraoperative measurement of cardiac output by thermodilution and transtracheal Doppler. Anesthesiology 1991, 74(4):664-669.

33. Perrino AC, Jr., Fleming J, LaMantia KR: Transesophageal Doppler ultrasonography: evidence for improved cardiac output monitoring. Anesth Analg 1990, 71(6):651657.

34. Dark PM, Singer M: The validity of transesophageal Doppler ultrasonography as a measure of cardiac output in critically ill adults. Intensive Care Med 2004, 30 (11):2060-2066.

35. Mythen MG, Webb AR: Perioperative plasma volume expansion reduces the incidence of gut mucosal hypoperfusion during cardiac surgery. Arch Surg 1995, 130 (4):423-429.

36. Perrino AC, Jr., Fleming J, LaMantia KR: Transesophageal Doppler cardiac output monitoring: performance during aortic reconstructive surgery. Anesth Analg 1991, 73(6):705-710.

37. Lefrant JY, Bruelle P, Aya AG, Saissi G, Dauzat M, de La Coussaye JE, Eledjam JJ: Training is required to improve the reliability of esophageal Doppler to measure cardiac output in critically ill patients. Intensive Care Med 1998, 24(4):347-352.

38. Valtier B, Cholley BP, Belot JP, de la Coussaye JE, Mateo J, Payen DM: Noninvasive monitoring of cardiac output in critically ill patients using transesophageal Doppler. Am J Respir Crit Care Med 1998, 158(1):77-83.

39. Poelaert J, Schmidt C, Van Aken H, Hinder F, Mollhoff T, Loick HM: A comparison of transoesophageal echocardiographic Doppler across the aortic valve and the thermodilution technique for estimating cardiac output. Anaesthesia 1999, 54(2):128 -136 .

40. Ryan T, Page R, Bouchier-Hayes D, Cunningham AJ: Transoesophageal pulsed wave Doppler measurement of cardiac output during major vascular surgery: comparison with the thermodilution technique. Br J Anaesth 1992, 69(1):101104.

41. Wiesenack C, Fiegl C, Keyser A, Prasser C, Keyl C: Assessment of fluid responsiveness in mechanically ventilated cardiac surgical patients. European journal of anaesthesiology 2005, 22(9):658-665.

42. Kubicek WG, Karnegis JN, Patterson RP, Witsoe DA, Mattson RH: Development and evaluation of an impedance cardiac output system. Aerosp Med 1966, 37(12):12081212.

43. Donovan KD, Dobb GJ, Woods WP, Hockings BE: Comparison of transthoracic electrical impedance and thermodilution methods for measuring cardiac output. Crit Care Med 1986, 14(12):1038-1044. 